\title{
Ecology of Typha domigensis Pers
}

\author{
Umesh Koirala $^{1}$, Sasinath Jha ${ }^{1}$ and Kedar Nath Ghimire ${ }^{2}$ \\ ${ }^{1}$ Department of Botany \\ Post Graduate Campus, Tribhuvan University, Biratnagar, Nepal \\ ${ }^{2}$ Central Department of Chemistry \\ Tribhuvan University, Kirtipur, Kathmandu, Nepal \\ E-mail: umesh6977@hotmail.com
}

\begin{abstract}
In a shallow pond at Biratnagar, Nepal, importance value index of $T$. domingensis ranged between 134 (September) and 179 (May), and net primary productivity of the plant along with associated species was 1001.23 $\mathrm{g} / \mathrm{m}^{2} / \mathrm{yr}$. Maximum concentrations of nitrogen $(2.76 \%)$ and potassium $(2.87 \%)$ occurred in leaves, and phosphorus $(0.95 \%)$ in roots of the plant in January, and three month old air-dried seeds of the plant had optimum germination (84\%) under red light on moist filter papers. The pond water had minimum values of $\mathrm{pH}(6.12)$, turbidity (51.2 NTU), conductivity (5.39 $\mathrm{ds} / \mathrm{m})$, total dissolved solids $(75.5 \mathrm{mg} / \mathrm{l}$, nitrate and nitrite $(0.01 \mathrm{mg} / \mathrm{l})$ and potassium $(5.6 \mathrm{mg} / \mathrm{l})$ in September; total nitrogen $(1.01 \mathrm{mg} / \mathrm{l})$ in May; and ammonia $(0.26 \mathrm{mg} / \mathrm{l})$ and total phosphorus $(0.72 \mathrm{mg} / \mathrm{l})$ in January. The sediment (mud) of the pond was silty-sandy loam with annual averages of $\mathrm{pH}$ 6.6 , nitrogen $0.23 \%$, phosphorus $0.006 \%$, potassium $0.04 \%$, organic carbon $4.05 \%$ and $\mathrm{C} / \mathrm{N}$ ratio $17.6: 1$.
\end{abstract}

Key words: Biomass diversity indices, productivity, turnover rate, turnover time, nutrients, germination.

\section{Introduction}

Typha domingensis Pers. (T. angustifolia L. / T. angustata Chaub ex Bory; family Typhaceae), commonly called 'narrow-leaved cattail', is a perennial, erect, monoecious herb up to 1-2 m with creeping rhizomes. It is often dominant in freshwater marshes, pools, and along water courses in warm tropical regions of the world including South Asia, Africa and South Europe (Panda \& Das, 2004). In Nepal, the plant occurs up to $200 \mathrm{~m}$ altitude (Hara et al., 1978). At Biratnagar (lat. $\mathrm{N} 26^{\circ} 20^{\prime}$, long. E 87 $16^{\prime}$; altitude $72 \mathrm{~m} \mathrm{msl}$ ), the plant remains in arrested phase of growth from November to April. New plants sprout from rhizomes or germinate from seeds from May to July, and the plant enters into flowering-fruiting phase in August (Jha \& Jha, 2000). Its leaves are widely used for thatching and made into mats and screens. The rhizome is astringent and diuretic. The immature inflorescence is used as food. The plant is eaten by waterfowl and muskrats (O' Neil, 1949; Tilmant, 1975). Muskrats also construct their lodges with cattail, and blackbirds use cattail for perches (Hensen et al., 1988). The plant is also used to create wetlands for mitigating the effects of waste water treatment plants and landfills.

The present study deals with seasonal variations in importance value index (IVI), diversity indices, and biomass of $T$. domingensis and associated species occurring in a shallow pond (area $50 \mathrm{~m} \times 40 \mathrm{~m}$; depth of water in centre 1.5 and $0.4 \mathrm{~m}$ during rainy and summer season, respectively) at Biratnagar along with seasonal changes in concentrations of nitrogen, 
phosphorus and potassium in different parts of the plant and physico-chemical properties of water and mud of the pond. In general, climate of Biratnagar is tropical and monsoonic with three distinct seasons viz, rainy (mid-June to October), winter (November to February), and summer (March to mid-June). Average meteorological data indicate 1225, 5, and $188 \mathrm{~mm}$ rainfall; 25, 10.4 and $19.6^{\circ} \mathrm{C}$ minimum air temperature; $32.2,25$ and $33.6^{\circ} \mathrm{C}$ maximum air temperature; and $6,3.8$ and $7.3 \mathrm{~km} / \mathrm{h}$ wind speed during rainy, winter and summer season, respectively for the last five years (2008-2012).

\section{Materials and Methods}

Individuals of $T$. domingensis and the associated species of the shore area $(15 \mathrm{~cm}$ to $1 \mathrm{~m}$ water depth) were sampled by laying ten quadrats of $50 \mathrm{~cm} \times 50 \mathrm{~cm}$ size randomly for determination of IVI, diversity indices, and biomass at seasonal intervals (first week of January, May and September) in 2011. The IVI was calculated as the sum of relative frequency, relative density and relative cover (Curtis \&McIntosh, 1951), and diversity indices were determined as per the method of Simpson (1949), and Shannon and Weaver (1949). The net primary productivity (NPP) was calculated by summing the positive increments in dry biomass on successive sampling dates (Singh \& Yadava, 1974). The turnover rate was determined as per the method of Dahlman and Kucera (1965) as $\mathrm{T}=\mathrm{A} / \mathrm{B}$, where, $\mathrm{T}=$ turnover rate, $\mathrm{A}=\mathrm{NPP}, \mathrm{B}=$ maximum biomass; and turnover time as: $1 / \mathrm{T} \times 12$.

Seeds of $T$. domingensis, collected in the first week of January 2011, were evaluated for germination in petridishes $(4.5 \mathrm{~cm}$ dia) on filter paper saturated with distilled water under different light qualities from April 23 to May 2012. To represent different light qualities, three sets (each of 3 ) of petridishes were covered separately by blue, red and white cellophane papers, and one set of petridishes were covered with black carbon sheet to represent dark condition. Each petridish contained 25 seeds. Moisture in petridishes was maintained by daily monitoring with distilled water added as needed and germination was defined as radicle emergence. The petridishes were placed on a table in laboratory at room temperature which, in addition to diffuse light entering the lab through glass windows from dawn to dusk, received light for $8 \mathrm{~h}$ (between 9 a.m. to 5 p.m.) daily from $40 \mathrm{~W}$ fluorescent tube fixed in the lab ceiling at $1.5 \mathrm{~m}$ distance from the table surface. Seeds in light were inspected daily and the germinated seeds were counted and discarded, whereas those incubated in dark were not inspected until germination under light became static. The average daily maximum and minimum room temperature during the experimental period were 33 and $22^{\circ} \mathrm{C}$, respectively.

Plant and mud samples were analysed for nitrogen by Nessler's reagent method (Willard et at., 1974), phosphorus by chlorostannous-reduced molybdophosphoric blue color method (Furman 1962), and potassium by flame photometer method (Piper, 1944). The texture of the mud was determined by sieving and weighing method (Piper, 1944), and organic carbon by Walkley and Black's (1934) method. Among the physico-chemical parameters of water samples, pH was determined by digital $\mathrm{pH}$ meter; conductivity by electrical conductivity meter (Willard et al., 1974); turbidity (nephelometric method), phosphorus (vandomolybdophospheric acid colorimetric method), total nitrogen (macro Kjeldahl method), nitrate and nitrite (UV spectrophotometric method), and potassium (atomic absorption spectrophotometric method) by 
APHA's (1990) methods; and total dissolved solids by the method of U.S. Geological Survey (1974).

\section{Results and Discussion}

(a) IVI, diversity indices, biomass and productivity: IVI of $T$ domingensis ranged between 134 (September) and 179 (May), and species next to T. domingensis in IVI were Alternanthera philoxeroides (68) and Ipomoea aquatica (23) in January; Ipomoea carnea subsp. fistulosa (33) and I. aquatica (30) in May; and A. philoxeroides (62), I. carnea subs fistulosa (33) and Eichhornia crassipes (30) in September (Table 1). McCann (2000) has opined that as real populations are variable, it is possible that the persistence of complex communities depends to some degree on population fluxes (that is, the fairly regular waxing and waning of a population's demsity). Such background population variability, whether driven by biotic or abiotic processes, can provide species with opportunity to respond differentially to their environment. In turn, these differential responses weaken the destructive potential of competitive exclusion.

Both Simpson's and Shannon-Weiner's index of diversity had minimum value (0.6 and 1.28, respectively) in May and maximum (0.72 and 1.51, respectively) in September (Table 1). These findings were in agreement with Krebs (1972) that diversity increases as any particular stress (water level, nutrients, etc.) lessens. According to Tilman (2000), greater diversity leads to greater productivity, greater nutrient retention in ecosystem, and greater ecosystem stability.

Table 1. Seasonal variations in IVI (mean \pm SE; $n=10$ ) of macrophytes and diversity indices in Typha domingensis association.

\begin{tabular}{lccc}
\hline \multicolumn{1}{l}{ January } & May & September \\
\hline A. IVI & & & \\
Alternanthera philoxeroides & $68 \pm 2$ & $25 \pm 2$ & $62 \pm 2$ \\
Eichhornia crassipes & $16 \pm 1$ & $23 \pm 1$ & $30 \pm 2$ \\
Ipomoea aquatica & $23 \pm 1$ & $30 \pm 2$ & $25 \pm 2$ \\
I. carnea subsp. fistulosa & $17 \pm 2$ & $33 \pm 2$ & $33 \pm 2$ \\
Marsilea minuta & $09 \pm 1$ & - & - \\
Polygonum glabrum & $11 \pm 1$ & $10 \pm 1$ & $16 \pm 1$ \\
Typha domingensis & $164 \pm 4$ & $179 \pm 4$ & $134 \pm 4$ \\
\hline B. Diversity indices & & & \\
Simpson's index & 0.64 & 0.60 & 0.72 \\
Shannon-Weiner's index & 1.40 & 1.28 & 1.51 \\
\hline
\end{tabular}

The biomass of $T$. domingensis ranged between 996.14 (January) and $1640.44 \mathrm{~g} / \mathrm{m}^{2}$ (September) (Table 2). Species next to T. domingensis in biomass value were I. carnea subsp fistulosa and $E$. crassipes (70.71 and $27.65 \mathrm{~g} / \mathrm{m}^{2}$, respectively) in January; I. carnea subsp. fistulosa and Polygonum glabrum (69.54 and $45.76 \mathrm{~g} / \mathrm{m}^{2}$, respectively) in May; and P. glabrum and I. carnea subsp. fistulosa (300.08 and $73.85 \mathrm{~g} / \mathrm{m}^{2}$, respectively) in September. Keddy (1992) likened water-level fluctuations in wetlands to fires in forests. They suppress one growth form in favour of another and allow regeneration of species from propagules. In agreement with this generalization, there was negligible change in biomass value of the association in January and May but biomass increased by $73.4 \%$ in September in comparison to May. 
Table 2. Seasonal variations in biomass $\left(\mathrm{g} / \mathrm{m}^{2}\right)$ (mean $\pm \mathrm{SE} ; \mathrm{n}=3$ ) in Typha domingensis and associated species.

\begin{tabular}{llll}
\hline Plants & January & May & September \\
\hline Alternanthera philoxeroides & $19.26 \pm 1.39$ & $26.63 \pm 1.63$ & $52.22 \pm 2.28$ \\
Eichhornia crassipes & $27.65 \pm 1.66$ & $28.80 \pm 1.70$ & $36.00 \pm 1.90$ \\
Ipomoea aquatica & $21.01 \pm 1.45$ & $25.00 \pm 1.58$ & $52.2 \pm 2.28$ \\
I. carnea subsp. fistulosa & $70.71 \pm 2.66$ & $69.54 \pm 2.64$ & $73.85 \pm 2.72$ \\
Marsilea minuta & $00.08 \pm 0.09$ & - & - \\
Polygonun glabrum & $20.00 \pm 1.41$ & $45.76 \pm 2.14$ & $300.06 \pm 5.48$ \\
Typha domingensis & $996.14 \pm 9.98$ & $1046.80 \pm 10.23$ & $1640.44 \pm 12.81$ \\
\hline Total & 1154.85 & 1242.53 & 2154.83 \\
\hline
\end{tabular}

The productivity of $T$. domingensis association was $1001.23 \mathrm{~g} / \mathrm{m}^{2} / \mathrm{yr}$. in which percentage contribution of associated species were in the order: T. domingensis (64) $>P$. glabrum (28) $>A$. philoxeroides and I. aquatica (3 each) $>$ E. crassipes and I. carnea subsp. fistulosa (1 each) (Table 3). Mitsch and Gosselink (2000) have stated that NPP is between $100-500 \mathrm{~g} / \mathrm{m}^{2} / \mathrm{yr}$ in lownutrient wetlands, whereas in high- nutrient wetlands NPP is between $1000-4000 \mathrm{~g} / \mathrm{m}^{2 /} \mathrm{yr}$. According to Kroll et al. (1997), shallow-water conditions usually result in the highest productivity whereas deep-water conditions offer the least potential for both emergent plants and invading, undesirable plants.

Turnover rate or renewal rate indicates how rapidly the concerned species in the system is replaced, whereas turnover time or residence time is a measure of the average time that the species remains in the system. In the present study, turnover rate was recorded as 63, 39 and $23 \%$, respectively, and turnover time 19, 31 and 52 months, respectively for A. philoxeroides, $T$. domingensis, and E. crassipes (Table 3). For Nelumbo nucifera association, Jha et al. (2004) have recorded 77.78, 88.89 and 6\% turnover rate, and 9, 14, 57 month turnover time for $N$. nucifera, E. crassipes and T. domingensis, respectively. Hence, it may be concluded that the same species responds differentially to the varying environmental conditions in terms of renewal rate and residence time.

Table 3. Productivity, turnover rate and turnover time of Typha domingemsis and associated species.

\begin{tabular}{lccc}
\hline Plants & $\begin{array}{c}\text { Productivity } \\
\left(\mathbf{g} / \mathbf{m}^{2} / \mathbf{y r}\right)\end{array}$ & $\begin{array}{c}\text { Turnover } \\
\text { rate }(\%)\end{array}$ & $\begin{array}{c}\text { Turnover time } \\
\text { (months) }\end{array}$ \\
\hline Alternanthera philoxeroides & 32.96 & 63 & 19 \\
Eichhornia crassipes & 835 & 23 & 52 \\
Ipomoea aquatica & 31.23 & 60 & 19 \\
I. carnea subsp. fistulosa & 4.31 & 06 & 17 \\
Polygonun glabrum & 280.08 & 93 & 13 \\
Typha domingensis & 644.30 & 39 & 31 \\
\hline
\end{tabular}

(b) Nutrients: Internal concentration of nitrogen, phosphorus and potassium considered adequate (to prevent deficiency symptoms) for most higher plants is $1.5,0.2$ and $1 \%$, respectively (Salisbury \& Ross, 1992). Accordingly, internal concentration of all these nutrients in $T$. domingensis was more than adequate throughout the year except nitrogen in May and September (Table 4). Although moderate excess of the nutrients than plant's requirements seems to offer no further advantage for growth, but it cannot be excluded that other ecologically important 
properties conferring competitive advantages-such as resistance to parasites or extreme climatic situations are in fact promoted (Larcher, 1975).

Table 4. Seasonal variations in percentage concentrations of nitrogen, phosphorus, and potassium in different parts of Typha domingensis (mean $\pm \mathrm{SE} ; \mathrm{n}=3$ ).

\begin{tabular}{|c|c|c|c|c|c|c|c|c|c|}
\hline \multirow{2}{*}{ Plant parts } & \multicolumn{3}{|c|}{ January } & \multicolumn{3}{|c|}{ May } & \multicolumn{3}{|c|}{ September } \\
\hline & $\mathbf{N}$ & $\mathbf{P}$ & $\mathbf{K}$ & $\mathbf{N}$ & $\mathbf{P}$ & $\mathbf{K}$ & $\mathbf{N}$ & $\mathbf{P}$ & $\mathbf{K}$ \\
\hline \multirow[t]{2}{*}{ Roots } & 1.33 & 0.95 & 1.75 & 1.05 & 0.80 & 1.05 & 1.05 & 0.75 & 0.70 \\
\hline & \pm 0.66 & \pm 0.55 & \pm 0.76 & \pm 0.59 & \pm 0.50 & \pm 0.59 & \pm 0.59 & \pm 0.50 & \pm 0.47 \\
\hline \multirow[t]{2}{*}{ Stems } & 0.80 & 0.45 & 2.80 & 1.22 & 0.45 & 2.00 & 0.59 & 0.40 & 0.32 \\
\hline & \pm 0.50 & \pm 0.38 & \pm 0.96 & \pm 0.63 & \pm 0.38 & \pm 0.81 & \pm 0.44 & \pm 0.36 & \pm 0.31 \\
\hline \multirow[t]{2}{*}{ Leaves } & 2.76 & 0.85 & 2.87 & 0.98 & 0.42 & 2.37 & 1.08 & 0.35 & 2.10 \\
\hline & \pm 0.95 & \pm 0.52 & \pm 0.97 & \pm 0.56 & \pm 0.37 & \pm 0.88 & \pm 0.60 & \pm 0.33 & \pm 0.83 \\
\hline Inflorescences & $\begin{array}{c}1.85 \\
\pm 0.78\end{array}$ & $\begin{array}{c}0.60 \\
\pm 0.44\end{array}$ & $\begin{array}{c}1.62 \\
\pm 0.73\end{array}$ & - & - & - & - & - & - \\
\hline
\end{tabular}

(c) Germination: Seeds of $T$. domingensis were pink to reddish-black, cylindrical in shape, and weight of 500 air-dried seeds was $1 \mathrm{mg}$. Three month old air-dried seeds exhibited high percentage of germination under red (84) and white light (78), but only 40 and $36 \%$ germination under blue light and dark condition, respectively (Fig. 1). The requirement of red or white light for better germination indicated phytochrome mediated response-both the light qualities maintain phytochrome in active form that triggers germination (Jha \& Jha, 2006).

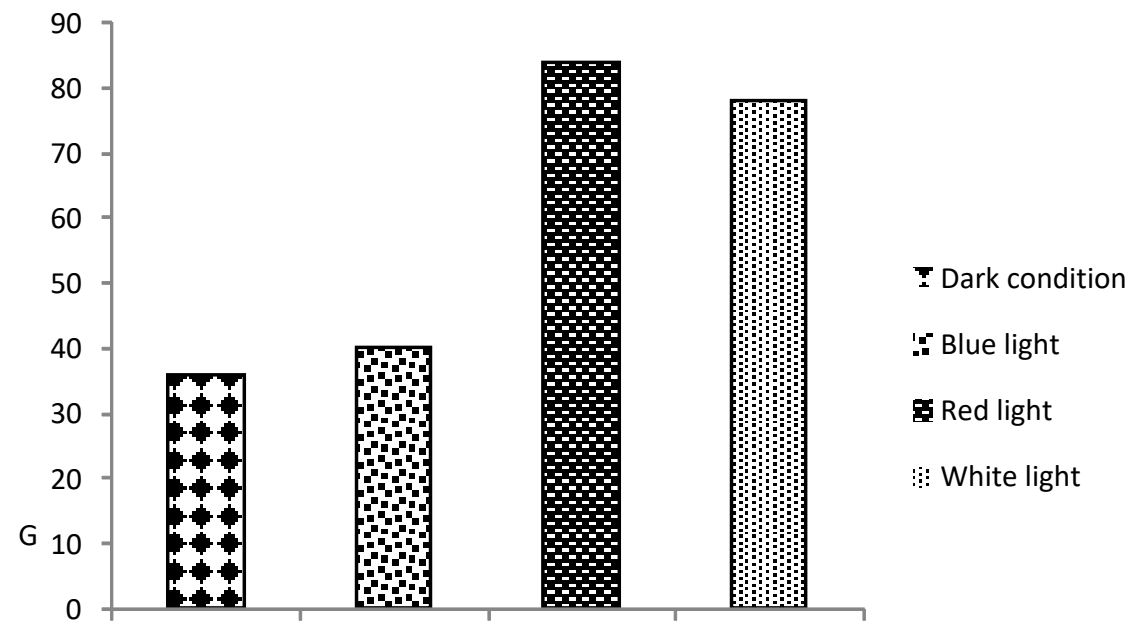

Figure 1. Percentage germination of Typha domingensis seeds under different colours of light and dark condition $(n=3)$.

(d) Pond water and mud: Pond water had minimum values of $\mathrm{pH}$ (6.12), total dissolved solids (51.2 $\mathrm{mg} / \mathrm{l})$, nitrite and nitrate $(0.01 \mathrm{mg} / \mathrm{l}$, each), and potassium $(5.6 \mathrm{mg} / \mathrm{l})$ in September; turbidity $(51.2 \mathrm{NTU})$, conductivity $(5.39 \mathrm{ds} / \mathrm{m})$, ammonia $(0.26 \mathrm{mg} / \mathrm{l})$ and phosphorus $(0.72$ $\mathrm{mg} / \mathrm{l})$ in January; and nitrogen $(1.01 \mathrm{mg} / \mathrm{l})$ in May; whereas maximum values of turbidity (132 NTU), total dissolved solids $(2695 \mathrm{mg} / \mathrm{l})$, total nitrogen $(6.86 \mathrm{mg} / \mathrm{l})$, nitrite and nitrate $(0.05$ 
$\mathrm{mg} / \mathrm{l})$ were recorded in January, and those of $\mathrm{pH}(6.64$, conductivity $(1088 \mathrm{ds} / \mathrm{m})$, ammonia $(6.71$ $\mathrm{mg} / \mathrm{l})$, phosphorus $(7.56 \mathrm{mg} / \mathrm{l})$ and potassium $(44.1 \mathrm{mg} / \mathrm{l})$ in May (Table 5). In general, minimum values of the recorded parameters can be attributed to increase in water level and utilization of nutrients by live biomass, and maximum values to fixation of nitrogen by cyanobacteria, mineralization of organic matter, and sparse vegetation in the pond.

Table 5. Seasonal variations in physico-chemical properties of water (mean \pm $\mathrm{SE} ; \mathrm{n}=3$ ) in Typha domingensis association.

\begin{tabular}{llll}
\hline & January & May & September \\
\hline $\mathrm{pH}$ & $6.55 \pm 1.47$ & $6.64 \pm 1.48$ & $6.12 \pm 1.42$ \\
Conductivity (ds/m) & $5.39 \pm 1.33$ & $1088.00 \pm 19.02$ & $140.50 \pm 6.84$ \\
Turbidity (NTU) & $132.00 \pm 6.69$ & $93.00 \pm 5.56$ & $51.20 \pm 4.12$ \\
Total dissolved solids (mg/l) & $2695.00 \pm 29.96$ & $544.00 \pm 13.45$ & $75.50 \pm 5.00$ \\
Total nitrogen (mg/l) & $6.86 \pm 1.50$ & $1.01 \pm 0.57$ & $2.30 \pm 0.87$ \\
Ammonia (mg/l) & $0.26 \pm 0.28$ & $6.71 \pm 1.49$ & $1.05 \pm 0.59$ \\
Nitrate (mg/l) & $0.05 \pm 0.12$ & $0.05 \pm 0.12$ & $0.01 \pm 0.05$ \\
Nitrite (mg/l) & $0.05 \pm 0.12$ & - & $0.01 \pm 0.05$ \\
Total phosphorus (mg/l) & $0.72 \pm 0.48$ & $7.56 \pm 1.58$ & $1.65 \pm 0.74$ \\
Potassium (mg/l) & $14.43 \pm 2.19$ & $44.10 \pm 3.83$ & $5.60 \pm 1.36$ \\
\hline
\end{tabular}

The silt particles $(50.7 \%)$ dominated the texture and mud (soil) had only $4.05 \%$ organic carbon on average (Table 6) which is a characteristic of the mineral soil. According to Mitsch and Gosselink (2000), mineral soils occur in freshwater marshes and riparian forests in which $\mathrm{pH}$ is circumneutral and nutrient availability is high. The soil, in general, had higher concentration of phosphorus $(0.006 \%)$ in comparison to those wetlands inhabiting Eichhornia-Lemna-Spirodela $(0.002 \%)$, Nelumbo $(0.003 \%)$ or Nymphaea $(0.003 \%)$ associations in eastern Nepal (Koirala, 2013). It was in agreement with $\mathrm{Li}$ et al. (2010) that $T$. domingensis is adapted to high phosphorus environments. In comparison to a round the year grazed grassland at Biratnagar which has 14.5:1 C/N ratio (Jha, 2010), pond mud had 17.1:1 C/N ratio due to accumulation of excess organic matter as a result of decreased decomposition in anaerobic environment.

Table 6. Seasonal variations in physico-chemical properties of mud in Typha domingensis association (mean \pm SE; $\mathrm{n}=3$ ).

\begin{tabular}{lccc}
\hline & January & May & September \\
\hline $\mathrm{pH}$ & $6.8 \pm 1.5$ & $6.8 \pm 1.5$ & $6.1 \pm 1.4$ \\
\hline Texture (\%) & & & \\
$\quad$ Sand & - & - & $29.1 \pm 3.1$ \\
$\quad$ Silt & - & - & $50.7 \pm 4.1$ \\
$\quad$ Clay & - & - & $20.2 \pm 2.6$ \\
\hline Nutrients (\%) & & & \\
N & $0.24 \pm 0.28$ & $0.24 \pm 0.28$ & $0.23 \pm 0.28$ \\
P & $0.006 \pm 0.04$ & $0.007 \pm 0.04$ & $0.006 \pm 0.04$ \\
K & $0.042 \pm 0.11$ & $0.010 \pm 0.05$ & $0.065 \pm 0.14$ \\
\hline Organic carbon $(\%)$ & $4.12 \pm 1.17$ & $4.05 \pm 1.16$ & $3.97 \pm 1.14$ \\
\hline C/N ratio & $17.17: 1$ & $16.87: 1$ & $17.26: 1$ \\
\hline
\end{tabular}

In brief, findings of the present study will be helpful in better management of Typha stands in eastern Nepal from both economic and ecological viewpoints. 


\section{Acknowledgements}

Thanks are due to National Agricultural Research Council (NARC), Khumaltar, Lalitpur and SEAM-N (Strengthening of the Environmental Adminstration and Management at the local level, Nepal), Biratnagar for lab facilities.

\section{References}

APHA (American Public Health Association). 1990. Standard Methods for the Examination of water and waste water, $16^{\text {th }}$ edn. APHA, Inc., New York.

Curtis, J.T. \& R.P. McIntosh. 1951. An upland forest continuum in the prairie-forest border region of Wisconsin. Ecology 32: 476-498. http://dx.doi.org/10.2307/1931725

Dahlman, R.C. \& C.L. Kucera. 1965. Root productivity and turnover in native prairie. Ecology 46: 84-89. http://dx.doi.org/10.2307/1935260

Furman, N.H. (ed.). 1962. Standard Methods of Chemical Analysis, $6^{\text {th }}$ edn. D Van Nostrand Co., New Jersey.

Hara, H., W.T. Stearn \& L.H.J. Williams (eds). 1978. An Enumeration of the Flowering Plants of Nepal, Vol. 1. British Museum (Natural History), London.

Hensen, P.L W.S. Chadde \& R.S. Pfister. 1988. Riparian Dominance Types of Montana. University of Montana, Montana.

Jha, S, U. Koirala \& M. K. Khadka. 2004 Enumeration and Human Use of the Vascular Plants of Chimdi Lake and Adjoining Areas. Report, Forum for Protection of Public Interest (ProPublic), Regional Office, Biratnagar.

Jha, S. \& P.K. Jha. 2000. Contribution to the flora of Morang district and adjoining areas of Nepal. Lidia 5(1-2): 25-64.

Jha, S. \& P.K. Jha. 2006 . Germination responses of some forage species of eastern Terai, Nepal . Ecoprint 13: 49-60.

Jha, S. 2010. Seasonal changes in physico-chemical properties of soil and forage nutrients in a low land Nepalese grassland. Pakistan Journal of Plant Sciences 16(2): 51-63.

Keddy, P.A. 1992. Assembly and response rules: two goals for predictive community ecology. Journal of Vegetation Science 3. 157-164. http://dx.doi.org/10.2307/3235676

Koirala, U. 2013. Ecological Study of Wetland Macrophytecs Occurring in Morang District of Nepal. Ph.D. Thesis, Tribhuvan University, Kathmandu.

Krebs, C.J. 1972. Ecology: The Experimental Analysis of Distribution and Abundance. Harper and Row, New York.

Kroll, R.W., J.F. Gottgens \& B.P. Swartz. 1997. Wild rice to rip-rap: 120 years of habitat changes and management of a Lake Erie coastal marsh. Transactions of the $62_{n d}$ North American Wildlife and Natural Resources Conference 62: 490-500.

Larcher, W. 1975. Physiological Plant Ecology. Springer-Verlag, New York.

Li, S., J. Lissner, I.A. Mendelssohn, H. Brix., B. Lorenzen, K.L. Mckee \& S. Miao. 2010. Nutrient and growth responses of cattail (Typha domingeusis) to redox intensity and phosphate availability. Annals of Botany 105: 175-184. http://dx.doi.org/10.1093/aob/mcp213

McCann, K.S. 2000. The diversity stability debate. Nature 405: 228-233. http://dx.doi.org/10.1038/ 35012234

Mitsch, W.J. \& J.G. Gosselink. 2000. Wetlands. John Wiley and Sons, Inc., New York. 
O' Neil, T. 1949. The Muskrat in the Louisiana Coastal Marshes. Louisiana Department of Wildlife and Fisheries, Fish and Game Division, Federal Aid Section, New Orleans.

Panda, S. \& A.P. Das. 2004 Flora of Samblapur (Orissa). Bishen Singh Mahendra Pal Singh, Dehra Dun.

Piper, C.S. 1944. Soil and Plant Analysis. The University of Adelaide, Australia.

Salisbury, F.B. \& C.W. Ross. 1992. Plant Physiology, 4th edn. Wadsworth, Belmont.

Shannon, C.E. \& W. Weaver. 1994. The Mathematical Theory of Communication. University of Illinois, Urbana.

Simpson, E.H. 1949. Measurements of diversity. Nature 163:688. http://dx.doi.org/10.1038/163688a0

Singh, J.S. \& P.S. Yadava. 1974 . Seasonal variations in composition, plant biomass and net primary productivity of a tropical grassland at Kurukshetra, India. Ecological Monographs 44: 351376. http://dx.doi.org/10.2307/2937034

Tilman, D. 2000. Causes, consequences and ethics of biodiversity. Nature 405: 208-211. http://dx.doi.org/ 10.1038/35012217

Tilmant, J.T. 1975. Habitat Utilization by Rountailed Muskrats (Neofiber alleni) in Everglades National Park. M.S. Thesis, Humboldt State University, California.

U.S. Geological Survey. 1974. Methods for Collection and Analysis of Water Samples for Dissolved Minerals and Gases. U.S. Geological Survey, Washington, D.C.

Walkey, A.J. \& I.A. Black. 1934. An examination of method for determining organic carbon and nitrogen in soil. Journal of Agricultural Science 25: 589-609.

Willard, H.H., L.L. Merritt \& J.A. Dean. 1974. Instrumental Methods of Analysis, $5^{\text {th }}$ edn. D. Van Nostrand Co., New Jersey. 